Int. J. Dev. Biol. 59: 55-62 (2015)

doi: $10.1387 / \mathrm{ijdb} .150065 \mathrm{jh}$

\title{
Interdigital tissue regression in the developing limb of vertebrates
}

\author{
CARLOS I. LORDA-DIEZ, JUAN A. MONTERO, JUAN A. GARCIA-PORRERO and JUAN M. HURLE* \\ Departamento de Anatomía y Biología Celular and IDIVAL, Universidad de Cantabria. Santander, Spain
}

\begin{abstract}
Here we have chosen the regression of the interdigital tissue which sculpts the digits from the hand/foot plate in tetrapod embryos to review the most relevant aspects concerning the regulation and biological significance of programmed cell death. We gather abundant information showing that the initiation of the degenerative process is the result of a complex interplay between the different signaling pathways which are also responsible for limb outgrowth and skeletal tissue differentiation, rather than being regulated by a specific signaling pathway. The model further shows that once the death response is triggered, several different routes of cell disruption, including caspase-dependent apoptosis, lysosomal-mediated cell death, and even a cell senescence process, are activated in the interdigits to ensure their elimination. Transcriptional and structural changes accompanying the degenerative process, and their posible contribution to the control of the death process, are also revised in detail. Finally we survey a number of issues still awaiting clarification, such as the functional implication of interdigital cell death as a source of signals acting on the surrounding tissues, as occurs in the so called "regenerative cell death".
\end{abstract}

KEY WORDS: cell death, apoptosis, limb development, developmental senescence, lysosomal cell death

\section{Introduction}

The basic cellular processes accounting for growth, differentiation or degeneration of tissues and organs are conserved in embryonic, tumoral and adult tissues. This mechanistic uniformity allows researchers to choose, among many options, the most appropriate and informative models and assays to analyze basic biological problems of relevance in physiology and pathology. From this point of view, the regression of the interdigital tissue which sculpts the digits in vertebrate embryos is a paradigm of tissue remodeling, which can provide information for a better understanding of degenerative processes, not only in the embryo but in adult organs or tumours also.

Digits differentiate as radial condensations whithin the distal paddle-shaped region of the limb bud termed the autopod. The autopod contains skeletal progenitors of mesodermal origin covered by the ectoderm and its initial morphogenesis involves the following coordinate events: 1) the autopod as a whole undergoes outgrowth directed by the marginal ectoderm (termed AER) which delivers growth factors to stimulate proliferation of the subjacent mesodermal progenitors; 2) in the deepness of the autopod the progenitors condensate to form radial cartilage blastemas which become segmented into phalanges, and mantain outgrowth by incorporation of further progenitors at their distal tip, located in the zone subjacent to the AER; 3 ) in the interdigital regions progenitors are maintaned undifferentiated, but retain potential to form extra digits. When digits have attained almost their final number of phalanges, the AER cesses functioning first in the interdigits, and next in the digit tips (Gañan et al., 1988). Concomitantly with the regression of the $A E R$, the interdigital tissue arrests proliferation and undergoes massive cell death followed by degeneration of all the remaining tissue components, including blood vessels, and extracellular matrix (Fig. 1). In addition, local healthy cells and invading macrophages remove by phagocytosis the degenerating tissue (see Hurle et al., 1977; Francisco-Morcillo et al., 2014). In the latest stages of the process of chick embryos, the degenerated tissue, including macrophages and epithelial tissue is detached into the amniotic sac (Hurle and Fernandez-Teran 1983).

Variations in the extent of interdigit degeneration account for differences in the morphology of digits related with the functional specialization of vertebrate species to swim (webbed digits in

Abbreviations used in this paper: AER, apical ectodermal ridge; AIF, apoptotic inducing factor; BMP, bone morphogenetic protein; ECM, extracellular matrix; FGF, fibroblast growth factor; IGF, insulin growth factor; RA, retinoic acid; ROS, reactive oxygen species.

\footnotetext{
*Address correspondence to: Juan M. Hurlé. Departamento de Anatomía y Biología Celular. Facultad de Medicina, Santander 39011, Spain. Fax: 34-942-201903. E-mail: hurlej@unican.es
}

Accepted: 6 May 2015

ISSN: Online 1696-3547, Print 0214-6282 
duck or tortoises), to fly (bat wings), or to walk on land (chicken, human, lizards; reviewed by Hurle et al., 1996). Conversely, abnormal inhibition of interdigital cell death in species with free digits results in syndactyly. However, the morphology and estructure of the syndactylous tissue is quite variable (Malik, 2012). For example, there are soft tissue syndactylies caused by absence of interdigital tissue remodeling, and, osseous syndactylies, when two adjacent digits fuse each other, or when an ectopic skeletal pieces are formed in the interdigits. The later not always are due to inhibition of cell death.

\section{Regulation of interdigital tissue regression}

Inhibition of interdigital cell death followed by syndactlyly is observed after disruption of almost each of the growth-regulatory pathways active in the autopod at the stages of digit formation, including: BMP-signaling (Zou and Niswander, 1996; Wang et al., 2004; Maatouk et al., 2009); FGF-signaling (Wilkie et al., 2002; Pajni-Underwood et al., 2007); Wnt-signaling (Mukhopadhyay et al., 2001; Grotewold and Rüther, 2002; Ikegawa et al., 2008; Morello et al., 2008; Villacorte et al., 2010); all-trans-retinoic acid signaling (Ahuja et al., 1997b; Rodriguez-Leon et al., 1999; Zhao et al., 2010; Cunningham et al., 2011); and Notch-signaling (Jiang et al., 1998; Sidow et al., 1997; Pan et al., 2005). In other cases the function of secreted factors in the regressing interdigits is less understood. Diferent Slit ligands and their Robo receptors are expressed in the interdigits without a known functional significance (Vargesson et al., 2001). The participation of IGF-signaling in the control of interdigital cell death was also proposed on the basis of the interdigital expression of different members of the pathway during the stages of interdigital cell death (van Kleffens et al., 1998; Allan et al., 2001). However, gain- and loss-of-function mutations of this signalling pathway cause phenotypes related with growth rather than altered morphogenesis (see, Tripathi et al., 2009). Together these findings indicate that interdigital cell death and limb outgrowth are divergent outcomes resulting from imbalance in the intensity of activation of comun regulatory processes.

Treatments with growth factors and their antagonists, together with studies using conditional compound genetics have provided considerable advance to unravel the crostalk between those signaling pathways in the control of interdigital cell death. It has been shown that BMPs are pro-apoptotic signals because negatively regulate the expression of FGF in the AER, which in turn are survival signals for the undifferentiate mesoderm (Maatouk et al., 2009; Wong et al., 2012). It has been also shown that Wnt//catenin signaling in the ectoderm positively regulate expression of Fgf8 in the AER by antagonizing epithelial BMP signaling (Villacorte et al., 2010). Notch signaling also functions by regulating the expression of FGFs in the AER (Pan et al., 2005). The role of Retinoic acid signaling in interdigital cell death has been associated with an antagonistic interplay with FGF (Hernandez-Martinez et al., 2009) and a positive transcriptional influence on interdigital BMP gene expression (Rodriguez-Leon et al., 1999). In summary, all these studies point to FGFs produced by the AER as key signals required for survival of the subjacent mesenchymal tissue. However, additional direct effects of each signaling on the dying machinery cannot be discarded (see Hernandez-Martınez and Covarrubias, 2011). For example, it has been shown that retinoic acid down-regulates anti-apoptotic factors (Crocoll et al., 2002)

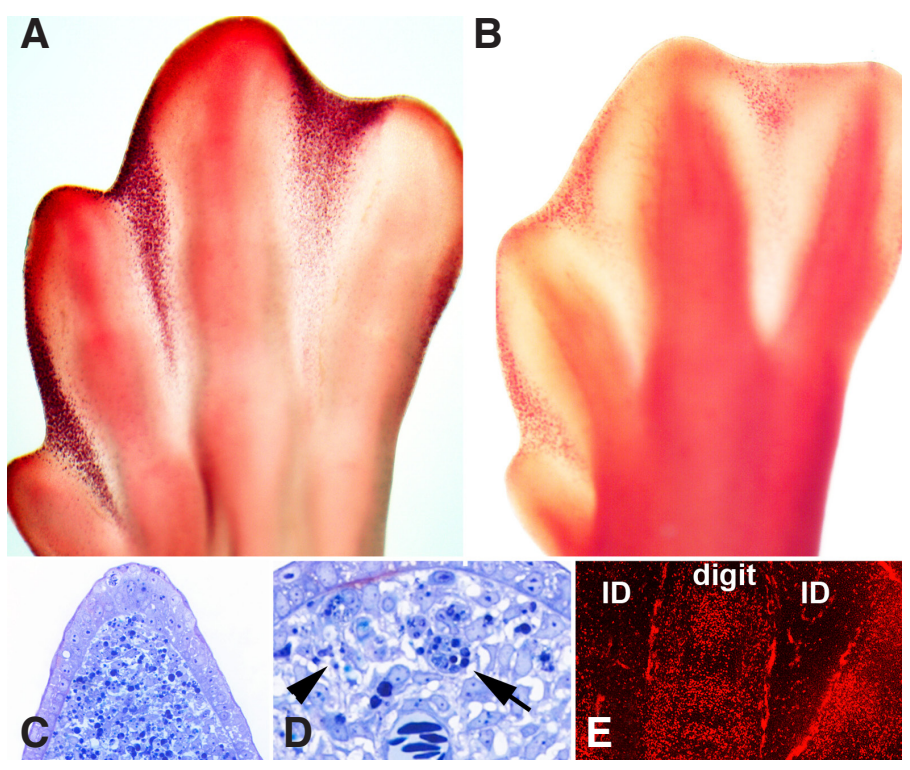

Fig. 1. Cell death and cell proliferation during the formation of the chick and duck toes. (A,B) The leg autopods of chick (A) and duck (B) embryos vital stained with neutral red to show differences in the intensity of interdigital cell death between species with free and webbed digits. (C,D) A low and high magnification view of the regressing chick interdigit after toluidine blue staining. Note that the interdigital tissue contains only mesodermal progenitors and blood vessels covered by the ectoderm (Ect). (D) A high magnification view to show the presence of isolated dying cells (arrow head) and large macrophages (arrow) in the regressing interdigit. (E) A section of the chick autopode showing BrdU incorporation in the digit rays (digit) and interdigital tissue (ID). Note the low labeling of the interdigital tissue in comparison with the digit rays. The autopod was incubated for 30 min in BrdU and immulabeled with anti-BrdU antibody.

and activates matrix proteinases associated with tissue remodeling (Dupé et al., 1999).

\section{Molecular machinery of cell death}

Most evidence show that interdigital cells employ redundant molecular machinery for self-destruction. The predominant death mechanism in the interdigits is apoptosis (Garcia-Martinez et al., 1993), but syndactyly is never observed by blocking a single molecular component of the apoptotic machinery.Consistent, with the apoptotic nature of cell death, numerous caspases (cysteineaspartic proteases), including initiator (caspase2, caspase 8, and caspase 9) and executioner caspases (caspase 3, caspase 6 and caspase 7; Fig. 2) are upregulated in the regressing interdigits (Nakanishi et al., 2001; Zuzarte-Luis et al., 2006), but interdigital cell death is not blocked in mice bearing single or compound caspase mutations, or deficient in caspase-activating adaptor protein, APAF-1 (Lakhani et al., 2006; Chautan et al., 1999; Kuida et al., 1998; Wang and Lenardo 2000; Nagasaka et al., 2009). It has been proposed that this apparent discrepancy is because interdigital mesenchyme die by necrosis if the apoptotic pathway is disrupted (Chautan et al., 1999).

Two distinct apoptotic pathways have been characterized in metazoa, the "extrinsic", which is mediated by death receptors present on the cell surface, and the "intrinsic", which results from the permeabilization of the mitochondria. Cytoplasmic release 
of cytochrome $\mathrm{C}$ and nuclear translocation of the mitochondrial proapototic factor AIF are central events in the intrinsic pathway which have been observed in the interdigital dying cells (ZuzarteLuis et al., 2006). Various pro- and anti-apoptotic factors involved in the permeabilization of the outer mitochondrial membrane, such as bcl-2, A1, bcl-x, Bag-1 (Carrio et al., 1996; Novack and Korsmeyer, 1994; Crocoll et al., 2002) show expression patterns consistent with their participation in interdigital cell death, but syndactyly is only observed in compound mutants afecting more than one of those pro-apoptotic factor. Syndactyly has been reported in triple-knockout, but not in single- or double-knockouts, of Bid, Bin and Puma (Ren et al., 2010); in double-knockout, but not in sigle-knockouts, of Bax and Bak (Lindsten et al., 2006; Ren et al., 2010); in double-knockout Bin and Bax, but not Bin and Bak (Hutcheson et al., 2005) and in double-knockout of Bin and Bmf (Hübner et al., 2010).

Lysosomes appear to be active partners of caspases during interdigital cell death. Lysosomal enzymes including cathepsins $B, D$, and $L$ are up-regulated at the onset of interdigital cell death (Fig. 2B) and down-regulated in syndactyly (Zuzarte-Luis et al., 2007). Up-regulation is observed in TUNEL positive apoptotic cells and is accompanied by tissue acidification and up-regulation of acidic cytoplasmic DNAses (Montero et al., 2010). The involvement of lysosomes is not contradictory with the above described sydactylysm observed in mice deficient for regulators of mitochondrial permeability (Jäättelä et al., 2004). Various regulators of the mitochondrial membrane are also able to permeabilize lysosomes, and dying cells induced by a mild activation of lysosomes take an apoptotic, rather than necrotic, morphology (Boya et al., 2003, Boya and Kroemer, 2008). Furthermore, Iysosomal enzymes are also able to activate caspases and induce mitochondrial permeabilization (Bidere et al., 2003). As observed for caspases, knockout of cathepsin genes lack syndactyly phenotype (Deussing et al., 1998) but interdigital cell death is inhibited in vitro by combined treatments with pan-caspase and lysosomal inhibitors (ZuzarteLuis et al., 2007).
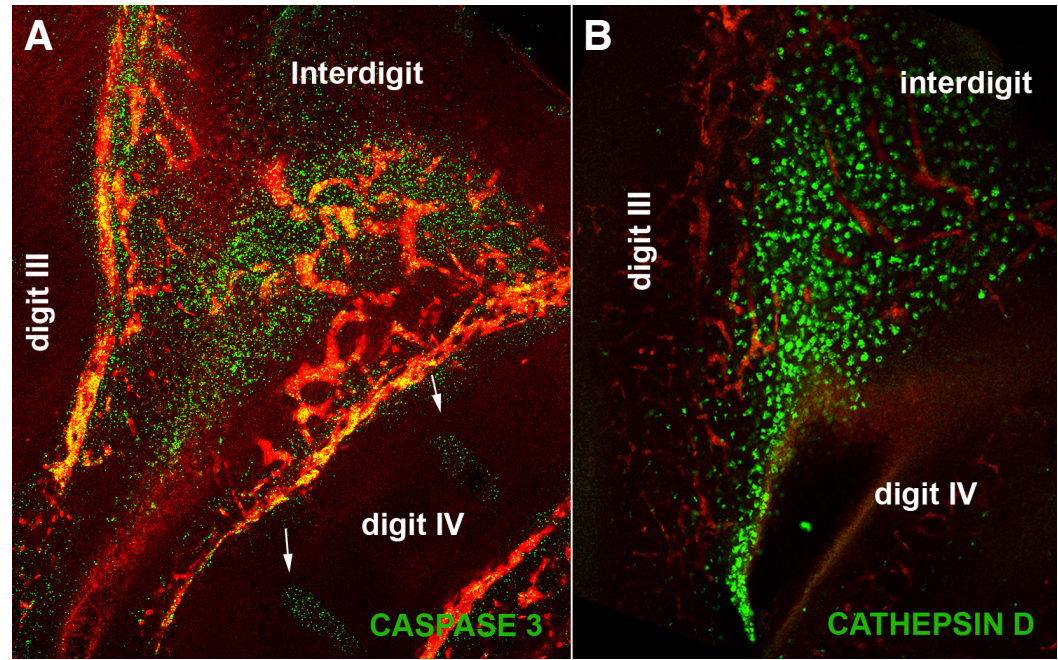

Fig. 2. Low magnification view of longitudinal sections of the third interdigit showning intense positivity for active caspase $3(A)$ and cathepsin $D(B)$ consistent with the involvement of caspase-dependent apoptosis and lysosomal cell death in the regression of the interdigital tissue. Note transverse domains of caspase 3 in digit IV (arrows) which mark the developing interphalangeal joints.
Morphological and immunohistochemical evidence indicates that, at advanced stages of interdigit tissue regression, autophagy also contributes to interdigital tissue regression (Montero et al., 2010), but this autophagic process has been related with a concomitant cell senescence process (see below; Storer et al., 2013).

In addition to the activation of apoptosis and lysosomes, oxidative stress might exert an important role in the establishment of the areas of interdigital cell death (Schnabel et al., 2006). The interdigital tissue, at difference of the digital regions, express low levels of genes encoding antioxidant enzymes such as superoxide dismutases, catalase and peroxidases (Schnabel et al., 2006; Shan et al., 2005), and reactive oxygen species increase in the interdigital tissue at the onset of cell death (Salas-Vidal et al., 1998). Furthermore, cell death is inhibited in vitro by antioxidant treatments (Salas-Vidal et al., 1998; Schnabel et al., 2006). Oxidative stress can damage most cell components, including mitochondrial and lysosomal membranes. Together these findings suggest a crosstalk between all the molecular players of interdigit regression. However, as observed for lysosomal enzymes and caspases, no syndactylous phenotype is appreciated in mice deficient in antioxidant enzymes (see Schnabel et al., 2006).

\section{Interdigital tissue regression as a potential model of developmental senescence}

Recent studies have shown that the molecular mechanisms characteristic of senescence also occur in a programmed manner during embryonic development (Nacher et al., 2006; Storer et al., 2013; Muñoz-Espin et al., 2013). There are not specific markers to define embryonic senescence processes but it is accepted that increased autophagy as detected by B-galactosidase activity, cell-cycle arrest, and matrix remodeling are indicators of physiological senescence. As described above, different degenerative cascades, including autophagy, are activated in the interdigital tissue (Montero et al., 2010; Storer et al., 2013). In addition, as will be analyzed below, interdigit remodeling is accopanied by growth arrest and matrix degradation.

\section{Cytoskeletal disruption and growth arrest}

Interdigit tissue regression is accompanied by inhibition of proliferation of interdigital cells (Fig. 1E; Toné and Tanaka, 1997). Some authors have emphasized that differential growth between the digits and interdigital regions exert a central influence in the process of digit individualization in the mouse (Salas-Vidal et al., 2001).

It has been shown that cycline $M$, the cyclin-dependent kinase inhibitor $1 \mathrm{~A}(\mathrm{p} 21)$, and cyclin-dependent kinases 5 and 10 are regulated in the course of tissue regression. Cyclin-dependent kinase 5 is intensely expressed at protein level in the interdigital apoptotic cells (Ahuja et al., 1997a; Zhang et al., 1997) but its upregulation appears to be secondary rather than a cause of apoptosis (Ye et al., 2012). In humans, loss of function mutation of cyclin M causes STAR syndrome characterized by syndactylysm and other malformations due to inhibition of physiological cell death (Guen et al., 2013). Cyclin $M$ activates cyclin-dependent kinase 10 and its loss of function up-regulates the activity of c-Raf.

The cyclin-dependent kinase inhibitor 1A, p21 is 
expressed in the interdigital tissue (Vasey et al., 2011). p21 is a negative regulator of cell-cycle progression which binds and inhibits the complexes formed between cyclins and cyclin-dependent kinases. It is important to remark, that this factor is considered a key effector of cell senescence in developing systems (MuñozEspin, et al., 2013).

Members of the Rho family GTP-binding proteins including Rac1 and Cdc42, with have biological functions in the organization of the cytoskeleton have been also related with interdigital cell death (Suzuki et al., 2009; Aizawa et al., 2012). Silencing either Rac1 or Cdc42 in the limb mesoderm using a Cre-recombinase transgenic approach is followed by inhibition of interdigital cell death and subsequent syndactily. However, these syndactylous phenotype have been related with a down-regulation of BMP signaling rather than having a direct effect on the apoptotic process (Suzuki et al., 2009; Aizawa et al., 2012).

The role of other genes with a direct influence on cell proliferation have received relative little attention. Members of the Myc and the Growth arrest specific (Gas) gene families have been proposed to participate in the control of interdigit regression (Lee et al., 1999; 2001; Ota et al., 2007). According to those studies, Gas1 inhibits the function of c-Myc and arrest interdigital cells at $G_{0}$ (Lee et al., 2001) in turn, Gas2 is a cytoskeletal component which is cleaved by caspase 3 inducing changes in cell morphology such as cell fragmentation (Lee et al., 1999). The role of $\mathrm{N}-\mathrm{Myc}$ in interdigit tissue regression is supported by the occurrence of syndactyly in humans haploinsuficient for N-Myc (van Bokhoven et al., 2005) and in mice with conditional deletion of N-Myc in the limb mesoderm (Ota et al., 2007). However, the role of $\mathrm{N}$-Myc deficiency in the genesis of syndactyly has been related with a defect in the formation of interdigital tissue rather than inhibition of cell death.

Besides the role in cell proliferation, cytoskeletal alterations may also account for nuclear and cytoplasmic fragmentation which are central events of apoptotic cell death. It has been proposed, that the process of cell fragmentation might be modulated by protein crosslinking and autophagy through the activation of tissue transglutaminase in the dying cells via retinoic acid signaling (Moallem and Hales, 1996; Piacentini et al., 2000; D’Eletto et al., 2012).

\section{Blood vessels and interdigital tissue regression}

The regression of the interdigits involves a massive process of mesodermal cell death and also the physical elimination of the interdigital tissue. This fact implies that blood vessels and the extracellular matrix need to be eliminated during individualization of the digits. However, the regression of interdigital blood vessels occurs at considerable late stages of degeneration (Hurle et al., 1985), discarding that cell death was secondary to hypoxia subsequent to the loss of blood vessels. This interpretation is supported by the distribution of markers of hypoxia in the developing digits instead than the interdigital regions (Huang and Hales, 2012). It is well known that the differentiating cartilages lack blood vessels and hypoxia promotes chondrogenic differentiation of the embryonic limb skeletal progenitors (Amarilio et al., 2007). Consistent with those findings it has been recently proposed that interdigital vasculature exerts a positive influence on cell death promoting the local production of ractive oxygen species (Eshkar-Oren et al., 2015).
Extracellular matrix, cell adhesion, and interdigital cell death

Syndactyly is a comun phenotype in humans and mice deficient in extracellular matrix components. In the stages previous to cell death, the interdigital tisue contains a very complex extracellular matrix which requires to be removed in the course of interdigit regression (Hurle et al., 1994; Díaz-Mendoza et al., 2013). The interdigits also show regulated expression domains of various extracellular matrix proteases (Carrol et al., 1994; Zhao et al., 2010). Alterations in the extracellular matrix may influence cell death by disrupting cell adhesion, by modifiying availability of growth factors, or, by losing its scaffolding function. Syndactyly is observed in humans and/ or mice deficient in laminin (Miner et al., 1998); nidogens (Böse et al., 2006); Fras1-related extracellular matrix gene 1 (Frem1; Smyth et al., 2004); SPARC(secreted protein acidic and rich in cysteine)-related modular calcium binding 1 (SMOC1; Okada et al., 2011); fibulin-1 (Debeer et al., 2002); fibrillin-2 (Arteaga-Solis et al., 2001; Chaudhry et al., 2001); versican degrading proteases ADAMTS (McCulloch et al., 2009; Nandadasa et al., 2014; Dubail et al., 2014).

In a complementary fashion, alterations of receptors responsible for anchoring cells to their surrounding matrix may be followed by disregulation of interdigit regression. It has been proposed the term "anoikis" to name cell death processes due to loss of cell anchoring to the extracellular matrix scaffold. Integrins are cell surface receptors that connect the ECM with the actin cytoskeleton. In the course of interdigit regression the extracellular matrix is broken down accompanied by alterations of downstream effectors of integrins such as decreased phosphorylation of the focal adhesion kinase FAK, and disintegration of paxillin which, via integrins, connect the cytoskeleton with the surrounding matrix (Zuzarte-Luis et al., 2006; Diaz-Mendoza et al., 2013). Together these findings point to an important role of cell-matrix adhesion in the onset of interdigital cell death, but syndactylous phenotypes caused by alteration of integrins are not very common and may reflect other roles of these receptors. Hence, althouh digit fusion is observed in mice with compound mutations of integrins $\alpha 3$ and $\alpha 6$ (De Arcangelis et al., 1999), syndactyly, in this case, appears to be due to abnormal development of the apical ectodermal ridge responsible for limb outgrowth. Other syndactylies accompaniying mutations of cell-cell adhesion molecules appear also due to disorganization of the ectodermal tissue (Brancati et al., 2010).

\section{Transcription factors and miRNAs associated with interdigital cell death and senescence}

The direct implication of transcription factors in the control of interdigital tissue regression is not fully understood. There are mouse mutants and human syndactylous syndromes, in which syndactyly appears to be secondary to defective growth rather than caused by a primary modification of the cell death process (Malik, 2012; Al-Qattan et al., 2013; Talamillo et al., 2010; Schatz and Ben-Arie, 2014). In other cases syndactyly is consequence of disruption of a signaling pathway regulated by the transcription factor. An example is the syndactly present in mice deficient in HoxA13 due to impairment in the synthesis of retinoic acid in the developing limb (Shou et al., 2013). In a similar fashion, the homeobox containing genes $M s x 1$ and $M s x 2$ are highly expressed in the undiferentiated limb mesoderm and interdigital tissue regression 
is inhibited in mouse double knockout for these genes, but not in single Msx1 or Msx2 mutant mice (Lallemand et al., 2005). It has been proposed that Msx2 have a direct effect on mesodermal cell death via regulation of BMP signaling (Ferrari et al., 1998). In addition, the morphological exam of the double mutants indicates that syndactyly is due to the persistence of an active AER in the interdigits (Lallemand et al., 2005).

Members of the Iroquois (Irx) homeobox gene family are expressed in a regulated and differential fashion with predominant digit (Irx1; Irx2) and interdigit (Irx3; Irx5; Irx6) domains (Zülch et al., 2001; McDonald et al., 2010; Díaz-Hernández et al., 2013). Consistent with a function of this gene family in interdigital tissue regression, syndactyly is a characteristic phenotype of the mouse mutant Fused toes (Ft) caused by a deletion of $1.6 \mathrm{Mb}$ of genomic sequences which include Irx3, Irx5, and Irx6 (Peters et al., 2002). Remarkably, Ft mice show abnormal patterns of expression of Bmp4, Fgf8 and the transcription factor Id3 in the developing autopod (Heymer and Rüther, 1999).

Of particular importance for the consolidation of the new hypothesis proposing the occurrence of an embryonic senescence process (Nacher et al., 2006; Storer et al., 2013; Muñoz-Espin et al., 2013) is the high expression of the transcription factor c-Rel in the regressing interdigits (Abbadie et al., 1993) and the presence of syndactyly in mice deficient in IKK $\alpha$ (Hu et al., 1999). The Rel/ NF-kB transcription factor family control cell-cycle, apoptosis, oxidative stress, immunity and inflammation and are considered central factors in aging and senescence (Gosselin and Abbadie, 2003).

It has been recently proposed that members of the AP-1 family of transcrition factors are major players in the control of limb programmed cell death. Several members of the family, including c-maf, Nfe211, Nfe212, Xbp1 and MafB, are expressed in the areas of programmed cell death (Lecoin et al., 2004; Suda et al., 2014). Functional studies of various members of the family have identified MafB as an important factor in the control of limb programmed cell death in the route of ROS-dependent apoptosis (Suda et al., 2014). According to this study, in the embryonic chick, but not in mouse, heterodimers of MafB/cFos are inhibitors of cell death whereas heterodimers MafB/cJun promote apoptosis.

MicroRNAs (miRNAs) are small (20-25 nucleotide-long) noncoding RNAs implicated in most biological processes by negatively regulating target specific genes through translational repression and/or by inducing mRNA degradation. Several miRNAs has been implicated in the control of embryonic programmed cell death in Drosophila (Ge et al., 2012), but no specific miRNAs has been yet involved in the control of interdigit tissue regression in vertebrates. However, knockdown of Dicer, a RNAase required for the formation of miRNAs, directed to the entire limb mesoderm caused intensification of mesodermal cell death suggesting the existence of miRNAs involved in cell survival (Harfe et al., 2005). It can be expected important advances in this topic in the near future.

\section{Concluding remarks}

Despite being a subject studied for many years through very different methodological approaches, we are still far from full understanding the molecular basis and the biological significance of interdigital cell death.

It is clear that various molecular mechanisms participate in this process of programmed cell death (caspases, lysosomes, autophagy) but we still need to clarify the precise contribution of each one, and to unravel how them interplay to ensure the separation of the digits when a dead route is blocked.

In a similar fashion we need to clarify the significance of developmental senescence in the regression of the interdigital tissue and its functional relation with cell death if they have it.

A emerging function of cell death in developmental systems and in tumours is to provide short and/or long-range signals to the neighbouring tissue able to modulate growth and differentiation (Boland et al., 2013; Vriz et al., 2014; Hurle 2014). Hence, we need to clarify if interdigital cell death is only a destructive process or if it is the source of signals for other tissues.

Although, a large body of information has been accumulated about the signaling regulators of the death machinery (FGFs; BMPs; $\mathrm{RA} ; \mathrm{ROS}$ ), we still lack a comprehensive view of this important issue.

Advances in these and other topics related with interdigital cell death could provide insights of relevance to understand degenerative diseases in human pathology and to develop strategies to improve cancer treatment.

\section{Acknowledgments}

This work was supported by a grant from the Spanish Science and Innovation Ministry to JMH (BFU2014-54026P).

\section{References}

ABBADIE, C., KABRUN, N., BOUALI, F., SMARDOVA, J., STÉHELIN, D., VANDENBUNDER, B., and ENRIETTO PJ. (1993).High levels of c-rel expression are associated with programmed cell death in the developing avian embryo and in bone marrow cells in vitro. Cell. 75: 899-912.

AHUJA, H.S., JAMES, W., and ZAKERI, Z. (1997a). Rescue of the limb deformity in hammertoe mutant mice by retinoic acid-induced cell death. Dev. Dyn. 208:466-481.

AHUJA H.S., ZHU Y., and ZAKERI Z. (1997b). Association of cyclin-dependent kinase 5 and its activator p35 with apoptotic cell death. Dev Genet.21: 258-267.

AL-QATTAN, M.M., SHAMSELDIN, H.E., ALMAZYAD, M., ALDEGHAITHER, S., and ALKURAYA, F.S. (2013) Genetic heterogeneity in type III familial cutaneous syndactyly and linkage to chromosome 7q36. Am. J. Med. Genet. A. 161A: 1579-1584

ALLAN, G.J., FLINT D.J., and PATEL K. (2001). Insulin-like growth factor axis during embryonic development. Reproduction 122: 31-39.

AMARILIO, R., VIUKOV, S.V., SHARIR, A., ESHKAR-OREN, I., JOHNSON, R.S., and ZELZER E. (2007). HIF1alpha regulation of Sox9 is necessary to maintain differentiation of hypoxic prechondrogenic cells during early skeletogenesis. Development 134: 3917-3928.

AIZAWA, R., YAMADA, A., SUZUKI, D., IIMURA, T., KASSAI, H., HARADA, T. TSUKASAKI, M., YAMAMOTO, G., TACHIKAWA, T., NAKAO, K., YAMAMOTO, M., YAMAGUCHI, A., AIBA, A., and KAMIJO R. (2012). Cdc42 is required for chondrogenesis and interdigital programmed cell death during limb development. Mech Dev. 129: 38-50.

ARTEAGA-SOLIS, E, GAYRAUD, B., LEE, S.Y., SHUM, L., SAKAI, L., and RAMIREZ, F. (2001). Regulation of limb patterning by extracellular microfibrils. J Cell Biol. 154: $275-281$.

BIDERE, N., LORENZO, H.K., CARMONA, S., LAFORGE, M., HARPER, F., DUMONT, C., and SENIK, A. (2003). Cathepsin D triggers Bax activation, resulting in selective apoptosis-inducing factor (AIF) relocation in T lymphocytes entering the early commitment phase to apoptosis. J. Biol. Chem. 278, 31401-31411.

BOLAND, K., FLANAGAN, L., and PREHN, J.H.M. (2013). Paracrine control of tissue regeneration and cell proliferation by Caspase-3. Cell death \& Disease 4: e725

BÖSE, K., NISCHT, R., PAGE, A, BADER, B.L., PAULSSON, M., SMYTH, N. (2006) Loss of nidogen-1 and -2 results in syndactyly and changes in limb development. J Biol Chem. 281: 39620-39629.

BOYA, P., ANDREAU, K., PONCET, D., ZAMZAMI, N., PERFETTINI, J.L., METIVIER, D., OJCIUS, D.M., JAATTELA, M., and KROEMER, G. (2003). Lysosomal membrane permeabilization induces cell death in a mitochondrion-dependent fashion. 
J. Exp. Med. 197, 1323-1334.

BOYA, P., and KROEMER, G. (2008). Lysosomal membrane permeabilization in cell death. Oncogene 27: 6434-6451.

BRANCATI, F., FORTUGNO, P., BOTTILLO, I., LOPEZ, M., JOSSELIN, E., BOUDGHENE-STAMBOULI, O., AGOLINI, E., BERNARDINI, L., BELLACCHIO, E., IANNICELLI, M., ROSSI, A., DIB-LACHACHI, A., STUPPIAL., PALKA, G., MUNDLOS, S., STRICKER, S., KORNAK, U., ZAMBRUNO, G., and DALLAPICCOLA, B. (2010). Mutations in PVRL4, encoding cell adhesion molecule nectin-4, cause ectodermal dysplasia-syndactyly syndrome. Am J Hum Genet. 87: 265-273

CARRIÓ, R., LÓPEZ-HOYOS, M., JIMENO, J., BENEDICT, M.A., MERINO, R., BENITO, A., FERNÁNDEZ-LUNA, J.L., NÚÑEZ, G., GARCÍA-PORRERO, J.A., and MERINO, J. (1996). A1 demonstrates restricted tissue distribution during embryonic development and functions to protect against cell death. Am J Pathol. 149: 2133-2142.

CARROLL, P.M., TSIRKA, S.E., RICHARDS, W.G., FROHMAN, M.A., and STRICKLAND, S. (1994). The mouse tissue plasminogen activator gene 5' flanking region directs appropriate expression in development and a seizure-enhanced response in the CNS. Development. 120: 3173-3183.

CHAUDHRY, S.S., GAZZARD, J., BALDOCK, C., DIXON, J., ROCK, M.J., SKINNER, G.C., STEEL, K.P., KIELTY, C.M., and DIXON, M.J. (2001). Mutation of the gene encoding fibrillin-2 results in syndactyly in mice. Hum Mol Genet. 10: 835-483.

CHAUTAN, M., CHAZAL, G., CECCONI, F., GRUSS, P., and GOLSTEIN, P. (1999). Interdigital cell death can occur through a necrotic and caspase-independent pathway. Curr Biol. 9: 967-970.

CROCOLL, A., HERZER, U., GHYSELINCK, N.B., CHAMBON, P., and CATO, A.C. (2002). Interdigital apoptosis and downregulation of BAG-1 expression in mouse autopods. Mech Dev. 111: 149-152.

CUNNINGHAM, T.J., CHATZI, C., SANDELL, L.L., TRAINOR, P.A., and DUESTER, G. (2011). Rdh10 mutants deficient in limb field retinoic acid signaling exhibit normal limb patterning but display interdigital webbing. Dev Dyn. 240: 1142-50.

DE ARCANGELIS, A., MARK, M., KREIDBERG, J., SOROKIN, L., and GEORGESLABOUESSE, E. (1999). Synergistic activities of alpha3 and alpha6 integrins are required during apical ectodermal ridge formation and organogenesis in the mouse. Development. 126: 3957-3968.

DEBEER, P, SCHOENMAKERS, E.F., TWAL, W.O., ARGRAVES, W.S., DE SMET, L., FRYNS, J.P., and VAN DE VEN, W.J. (2002). The fibulin-1 gene (FBLN1) is disrupted in a $t(12 ; 22)$ associated with a complex type of synpolydactyly. $J$ Med Genet. 39: 98-104.

D'ELETTO, M., FARRACE, M.G., ROSSIN, F., STRAPPAZZON F., GIACOMO, G.D., CECCONI F., MELINO, G., SEPE, S., MORENO, S., FIMIA, G.M., FALASCA, L., NARDACCI, R., and PIACENTINI, M. (2012). Type 2 transglutaminase is involved in the autophagy-dependent clearance of ubiquitinated proteins. Cell Death Differ. 19: 1228-1238.

DEUSSING, J., ROTH, W., SAFTIG, P., PETERS, C., PLOEGH, H.L., and VILLADANGOS, J.A.(1998). Cathepsins B and D are dispensable for major histocompatibility complex class II-mediated antigen presentation. Proc Natl Acad Sci USA. 95: 4516-4521.

DÍAZ-HERNÁNDEZ, M.E., BUSTAMANTE, M., GALVÁN-HERNÁNDEZ, C.I., and CHIMAL-MONROY, J. (2013). Irx1 and Irx2 are coordinately expressed and regulated by retinoic acid, TGF $\beta$ and FGF signaling during chick hindlimb development. PLoS One. 8:e58549.

DÍAZ-MENDOZA, M.J., LORDA-DIEZ, C.I., MONTERO, J.A., GARCÍA-PORRERO, J.A., and HURLÉ, J.M. (2013). Interdigital cell death in the embryonic limb is associated with depletion of Reelin in the extracellular matrix. Cell Death Dis. 4:e800.

DUBAIL, J., ARAMAKI-HATTORI, N., BADER, H.L., NELSON, C.M., KATEBI, N., MATUSKA, B., OLSEN, B.R., and APTE, S.S. (2014). A new Adamts9 conditional mouse allele identifies its non-redundant role in interdigital web regression. Genesis. 52: 702-712.

DUPÉ, V., GHYSELINCK, N.B., THOMAZY, V., NAGY, L., DAVIES, P.J., CHAMBON, P., and MARK, M. (1999). Essential roles of retinoic acid signaling in interdigital apoptosis and control of BMP-7 expression in mouse autopods. Dev Biol. 208:30-43.

ESHKAR-OREN, I., KRIEF, S., FERRARA, N., ELLIOTT, A.M., and ZELZER, E. (2015). Vascular patterning regulates interdigital cell death by a ROS-mediated mechanism. Development. 142: 672-680.

FERRARI, D., LICHTLER, A.C., PAN, Z.Z., DEALY, C.N., UPHOLT, W.B., and KOSHER R.A. (1098). Ectopic expression of Msx-2 in posterior limb bud mesoderm impairs limb morphogenesis while inducing BMP-4 expression, inhibiting cell proliferation, and promoting apoptosis. Dev Biol. 197: 12-24.

FRANCISCO-MORCILLO, J., BEJARANO-ESCOBAR, R., RODRÍGUEZ-LEÓN, J., NAVASCUÉS, J., MARTÍN-PARTIDO, G. (2014). Ontogenetic Cell Death and Phagocytosis in the Visual System of Vertebrates. Dev Dyn. 243: 1203-1225. (doi: 10.1002/dvdy.24174)

GARCIA-MARTINEZ V., MACIAS, D., GAÑAN, Y., GARCIA-LOBO, J.M., FRANCIA, M.V., FERNANDEZ-TERAN, M.A., and HURLE, J.M. (1993). Internucleosomal DNA fragmentation and programmed cell death (apoptosis) in the interdigital tissue of the embryonic chick leg bud. J Cell Sci. 106: 201-208.

GAÑAN, Y., MACIAS, D., BASCO, R.D., MERINO, R, and HURLE, J.M. (1998). Morphological diversity of the avian foot is related with the pattern of msx gene expression in the developing autopod. Dev Biol. 196: 33-41.

GE, W., CHEN, Y.W., WENG, R, LIM, S.F., BUESCHER, M., ZHANG, R., and COHEN, S.M. (2012). Overlapping functions of microRNAs in control of apoptosis during Drosophila embryogenesis. Cell Death Differ. 19: 839-846.

GOSSELIN, K., and ABBADIE, C. (2003). Involvement of Rel/NF-kappa B transcription factors in senescence. Exp Gerontol. 38: 1271-1283.

GROTEWOLD, L., and RÜTHER, U. (2002) The Wnt antagonist Dickkopf-1 is regulated by Bmp signaling and c-Jun and modulates programmed cell death. EMBO J. 21: 966-975.

GUEN, V.J., GAMBLE, C., FLAJOLET, M., UNGER, S., THOLLET, A., FERANDIN, Y., SUPERTI-FURGA, A., COHEN,P.A., MEIJER, L., and COLAS, P. (2013). CDK10/ cyclin $M$ is a protein kinase that controls ETS2 degradation and is deficient in STAR syndrome. Proc Natl Acad Sci USA. 110: 19525-19530.

HARFE, B.D, MCMANUS, M.T., MANSFIELD, J.H., HORNSTEIN, E., and TABIN, C.J. (2005). The RNasell enzyme Dicer is required for morphogenesis but not patterning of the vertebrate limb. Proc Natl Acad Sci USA. 102: 10898-10903.

HERNÁNDEZ-MARTÍNEZ, R., and COVARRUBIAS, L. (2011). Interdigital cell death function and regulation: new insights on an old programmed cell death model. Dev Growth Differ. 53: 245-258.

HEYMER, J., and RÜTHER, U. (1999). Syndactyly of Ft/+ mice correlates with an imbalance in bmp4 and fgf8 expression. Mech Dev. 88: 173-181.

HERNÁNDEZ-MARTÍNEZ,R., CASTRO-OBREGÓN, S., and COVARRUBIAS, L. (2009).Progressive interdigital cell death: regulation by the antagonistic interaction between fibroblast growth factor 8 and retinoic acid. Development. 136:3669-3678.

HU, Y., BAUD, V., DELHASE, M., ZHANG, P., DEERINCK, T., ELLISMAN, M., JOHNSON, R., and KARIN, M. (1999). Abnormal morphogenesis but intact IKK activation in mice lacking the IKKalpha subunit of IkappaB kinase. Science. 284: 316-320.

HUANG C., and HALES B.F. (2012). Effects of exposure to a DNA damaging agent on the hypoxia inducible factors in organogenesis stage mouse limbs. PLOS One. 7:e51937

HÜBNER, A., CAVANAGH-KYROS, J., RINCON, M., FLAVELL,R.A., and DAVIS, R.J. (2010). Functional cooperation of the proapoptotic Bcl2 family proteins Bmf and Bim in vivo. Mol Cell Biol. 30: 98-105.

HURLE, J.M. (2014). Regenerative versus Destructive cell death in developing systems and tissue homeostasis. Bioessays 36: 1020

HURLE, J.M., COLVEE, E., and FERNANDEZ-TERAN M.A. (1985). Vascular regression during the formation of the free digits in the avian limb bud: a comparative study in chick and duck embryos. J Embryol Exp Morphol. 85: 239-250.

HURLE, J.M., CORSON, G., DANIELS, K., REITER, R.S., SAKAI, L.Y., and SOLURSH M. (1994). Elastin exhibits a distinctive temporal and spatial pattern of distribution in the developing chick limb in association with the establishment of the cartilaginous skeleton. J Cell Sci. 107: 2623-2634.

HURLE, J.M., LAFARGA, M., and OJEDA, J.L. (1977). Cytological and cytochemical studies of necrotic area of bulbus of chick-embryo heart - phagocytosis by developing myocardial cells. J Embryol Exp Morphol 41: 161-173

HURLE, J.M., and FERNANDEZ-TERAN, M.A. (1983). Fine structure of the regressing interdigital membranes during the formation of the digits of the chick embryo leg bud. J Embryol Exp Morphol. 78: 195-209.

HURLE, J.M., ROS, M.A., CLIMENT, V., and GARCIA-MARTINEZ, V. (1996). Morphology and significance of programmed cell death in the developing limb bud of the vertebrate embryo. Microsc Res Tech. 34: 236-246.

HUTCHESON, J., SCATIZZI, J.C., BICKEL,E., BROWN, N.J., BOUILLET, P., STRASSER A., and PERLMAN H. (2005). Combined loss of proapoptotic genes Bak or Bax with Bim synergizes to cause defects in hematopoiesis and in thymocyte apoptosis. J Exp Med. 201: 1949-1960. 
IKEGAWA, M., HAN, H., OKAMOTO, A., MATSUI R., TANAKA M., OMI N, MIYAMAE M., TOGUCHIDA J., TASHIRO K. (2008). Syndactyly and preaxial synpolydactyly in the single Sfrp2 deleted mutant mice. Dev Dyn. 237: 2506-2517.

JÄÄTTELÄ, M., CANDÉ, C., and KROEMER, G. (2004). Lysosomes and mitochondria in the commitment to apoptosis: a potential role for cathepsin D and AIF. Cell Death Differ. 11: 135-6.

JIANG, R., LAN, Y., CHAPMAN, H.D., SHAWBER, C., NORTON, C.R., SERREZE, D.V., WEINMASTER, G., and GRIDLEY, T. (1998). Defects in limb, craniofacial, and thymic development in Jagged2 mutant mice. Genes Dev. 12: 1046-1057.

KUIDA, K., HAYDAR, T.F., KUAN, C.Y., GU, Y., TAYA, C., KARASUYAMA, H., SU, M.S., RAKIC, P., and FLAVELL, R.A. (1998). Reduced apoptosis and cytochrome C-mediated caspase activation in mice lacking caspase 9. Cell. 94: 325-337.

LAKHANI, S.A., MASUD, A., KUIDA, K., PORTER, G.A. JR, BOOTHC.J., MEHAL,W.Z., INAYAT, I., and FLAVELL, R.A. (2006). Caspases 3 and 7: key mediators of mitochondrial events of apoptosis. Science. 311: 847-851.

LALLEMAND, Y., NICOLA, M.A., RAMOS, C., BACH, A., CLOMENT, C.S., ROBERT, B. (2005). Analysis of Msx1; Msx2 double mutants reveals multiple roles for Msx genes in limb development. Development. 132: 3003-3014.

LECOIN, L., SII-FELICE, K., POUPONNOT, C., EYCHÈNE, A., and FELDERSCHMITTBUHL M.P. (2004). Comparison of maf gene expression patterns during chick embryo development. Gene Expr Patterns. 4: 35-46.

LEE, K.K., LEUNG, A.K., TANG, M.K., CAI, D.Q., SCHNEIDER, C., BRANCOLINI, C., and CHOW. P.H. (2001). Functions of the growth arrest specific 1 gene in the development of the mouse embryo. Dev Biol. 234: 188-203.

LEE K.K., TANG M.K., YEW D.T., CHOW P.H., YEE S.P., SCHNEIDER C., and BRANCOLINIC. (1999). gas2 is a multifunctional gene involved in the regulation of apoptosis and chondrogenesis in the developing mouse limb. Dev Biol. 207: 14-25.

LINDSTEN T., and THOMPSON C.B. (2006).Cell death in the absence of Bax and Bak. Cell Death Differ. 13: 1272-1276

MAATOUK D.M., CHOI K.S., BOULDIN C.M., and HARFE B.D. (2009). In the limb $\mathrm{AER}$ Bmp2 and Bmp4 are required for dorsal-ventral patterning and interdigital cell death but not limb outgrowth. Dev Biol. 327: 516-523.

MALIK S. (2012). Syndactyly: phenotypes, genetics and current classification. Eur $J$ Hum Genet. 20: 817-824.

MCDONALD L.A., GERRELLI D., FOK Y., HURST L.D., and TICKLE C. (2010). Comparison of Iroquois gene expression in limbs/fins of vertebrate embryos. $J$ Anat. 216: 683-691.

MCCULLOCHD.R., NELSON C.M., DIXON L.J., SILVERD.L., WYLIE J.D., LINDNER V., SASAKIT., COOLEYM.A., ARGRAVESW.S., and APTES.S. (2009). ADAMTS metalloproteases generate active versican fragments that regulate interdigital web regression. Dev Cell.17: 687-698.

MINER J.H., CUNNINGHAM J., and SANES J.R. (1998). Roles for laminin in embryogenesis: exencephaly, syndactyly, and placentopathy in mice lacking the laminin alpha5 chain. J Cell Biol. 143: 1713-1723.

MOALLEMA.S., and HALESB.F.(1996). Transglutaminase and clusterin induction during normal and abnormal limb development in the mouse. Biol Reprod. 55:281-290.

MONTERO J.A., LORDA-DIEZC.I., CERTALA.C., MORENON., RODRIGUEZ-LEON J., TORRIGLIAA., and HURLE J.M. (2010). Coordinated and sequential activation of neutral and acidic DNases during interdigital cell death in the embryonic limb. Apoptosis. 15: 1197-1210.

MORELLO R., BERTIN T.K., SCHLAUBITZ S., SHAW C.A., KAKURU S., MUNIVEZ E., HERMANNS P., CHEN Y., ZABEL B, and LEE B. (2008). Brachy-syndactyly caused by loss of Sfrp2 function. J Cell Physiol. 217: 127-137.

MUKHOPADHYAY M., SHTROM S., RODRIGUEZ-ESTEBAN C., CHEN L., TSUKUI T., GOMER L., DORWARD D.W., GLINKA A., GRINBERG A., HUANG S.P., NIEHRS C., IZPISÚA BELMONTE J.C., WESTPHAL H. (2001). Dickkopf1 is required for embryonic head induction and limb morphogenesis in the mouse. Dev Cell.1: 423-434.

MUÑOZ-ESPINND., CAÑAMEROM., MARAVERA., GÓMEZ-LÓPEZG., CONTRERAS J., MURILLO-CUESTAS., RODRÍGUEZ-BAEZAA., VARELA-NIETOI., RUBERTE J., COLLADO M., and SERRANO M. (2013). Programmed cell senescence during mammalian embryonic development. Cell.155: 1104-1118.

NACHER V., CARRETERO A., NAVARRO M., ARMENGOL C., LLOMBART C., RODRÍGUEZA., HERRERO-FRESNEDAI., AYUSO E., and RUBERTE J. (2006). The quail mesonephros: a new model for renal senescence? J Vasc Res. 43: 581-586.

NANDADASA S., FOULCER S., and APTE S.S. (2014). The multiple, complex roles of versican and its proteolytic turnover by ADAMTS proteases during embryogenesis. Matrix Biol. 35: 34-41

NAGASAKAA., KAWANEK., YOSHIDAH., and NAGATAS. (2010). Apaf-1-independent programmed cell death in mouse development. Cell Death Differ. 17: 931-941

NAKANISHI K., MARUYAMAM., SHIBATA T., and MORISHIMAN. (2001). Identification of a caspase- 9 substrate and detection of its cleavage in programmed cell death during mouse development. J Biol Chem. 276: 41237-44134.

NOVACKD.V., and KORSMEYERS.J. (1994). Bcl-2 protein expression during murine development. Am J Pathol. 145: 61-73.

OKADA, I., HAMANOUE, H., TERADA, K., TOHMA, T., MEGARBANE, A., CHOUERY E., ABOU-GHOCH J., JALKH N., COGULU, O., OZKINA, Y F, HORIE,K, TAKEDA J., FURUICHI, T., IKEGAWA, S., NISHIYAMA K., MIYATAKE, S., NISHIMURA A., MIZUGUCHI, T., NIIKAWA N., HIRAHARA, F., KANAME,T., YOSHIURA, K. TSURUSAKI, Y., DOI H., MIYAKE N., FURUKAWA, T., MATSUMOTO, N., and SAITSU, H. (2011). SMOC1 is essential for ocular and limb development in humans and mice. Am J Hum Genet. 88: 30-41.

OTA, S., ZHOU, Z.Q., KEENE, D.R., KNOEPFLER, P., and HURLIN, P.J. (2007). Activities of $\mathrm{N}-\mathrm{Myc}$ in the developing limb link control of skeletal size with digit separation. Development. 134: 1583-92.

PAJNI-UNDERWOOD, S., WILSON, C.P., ELDER, C., MISHINA, Y., and LEWANDOSKI M. (2007). BMP signals control limb bud interdigital programmed cell death by regulating FGF signaling. Development. 134: 2359-2368.

PAN, Y., LIU, Z., SHEN, J., and KOPAN, R. (2005). Notch1 and 2 cooperate in limb ectoderm to receive an early Jagged2 signal regulating interdigital apoptosis. Dev Biol. 286: 472-482.

PIACENTINI, M., RODOLFO, C., FARRACE, M.G., AUTUORI, F. (2000). "Tissue" transglutaminase in animal development. Int J Dev Biol. 44: 655-656

PETERS, T., AUSMEIER K., DILDROP R., and RÜTHERU. (2002). The mouse Fused toes $(\mathrm{Ft})$ mutation is the result of a $1.6-\mathrm{Mb}$ deletion including the entire Iroquois B gene cluster. Mamm Genome. 13: 186-188.

REN, D., TU, H.C., KIM, H., WANG, G.X., BEAN, G.R., TAKEUCHI, O., JEFFERS J.R., ZAMBETTI, G.P., HSIEH, J.J., and CHENG, E.H. (2010). BID, BIM, and PUMA are essential for activation of the BAX- and BAK-dependent cell death program. Science. 330: 1390-1393.

RODRIGUEZ-LEON, J., MERINO, R., MACIAS, D., GAÑAN, Y., SANTESTEBAN, E. and HURLE, J.M. (1999). Retinoic acid regulates programmed cell death through BMP signalling. Nat Cell Biol. 1: 125-126

SALAS-VIDAL, E., VALENCIA, C., and COVARRUBIAS, L. (2001) Differential tissue growth and patterns of cell death in mouse limb autopod morphogenesis. Dev Dyn. 220: 295-306.

SALAS-VIDAL, E., LOMELÍ, H., CASTRO-OBREGÓN, S., CUERVO, R., ESCALANTEALCALDE, D., and COVARRUBIAS, L. (1998). Reactive oxygen species participate in the control of mouse embryonic cell death. Exp Cell Res. 238: 136-147.

SCHATZ, O., and BEN-ARIE, E.L. (2014). Gene dosage of the transcription factor Fingerin (bHLHA9) affects digit development and links syndactyly to ectrodactyly. Hum Mol Genet. 23: 5394-5401.

SCHNABEL, D., SALAS-VIDAL, E., NARVÁEZ, V., SÁNCHEZ-CARBENTE, Mdel, R., HERNÁNDEZ-GARCÍA, D., CUERVO, R., and COVARRUBIAS, L. (2006). Expression and regulation of antioxidant enzymes in the developing limb support a function of ROS in interdigital cell death. Dev Biol. 291: 291-299.

SHAN, S.W., TANG, M.K., CAI, D.Q., CHUI, Y.L., CHOW, P.H., GROTEWOL,D L., and LEE K.K. (2005). Comparative proteomic analysis identifies protein disulfide isomerase and peroxiredoxin 1 as new players involved in embryonic interdigital cell death. Dev Dyn. 233: 266-281.

SHOU, S., CARLSON, H.L., PEREZ, W.D., and STADLER, H.S. (2013). HOXA13 regulates Aldh1a2 expression in the autopod to facilitate interdigital programmed cell death. Dev Dyn. 242: 687-698.

SIDOW, A., BULOTSKY, M.S., KERREBROCK, A.W., BRONSON R.T., DALY, M.J., REEVE, M.P., HAWKINS, T.L., BIRREN, B.W., JAENISCH, R., and LANDER, E.S. (1997). Serrate2 is disrupted in the mouse limb-development mutant syndactylism. Nature. 389: 722-725.

SMYTH, I., DU X., TAYLOR, M.S., JUSTICE, M.J., BEUTLER, B, and JACKSON, I.J. (2004). The extracellular matrix gene Frem1 is essential for the normal adhesion of the embryonic epidermis. Proc Natl Acad Sci USA. 101: 13560-1355.

STORER, M., MAS, A., ROBERT-MORENO, A., PECORARO M., ORTELLS, M.C. DI GIACOMO, V., YOSEF, R., PILPEL, N., KRIZHANOVSKY, V., SHARPE J., and 
KEYES, W.M. (2013). Senescence is a developmental mechanism that contributes to embryonic growth and patterning. Cell. 155: 1119-1130.

SUZUKI, D., YAMADA, A., AMANO, T., YASUHARA, R., KIMURA, A., SAKAHARA, M. TSUMAKI, N., TAKEDA, S., TAMURA, M., NAKAMURA, M., WADA, N., NOHNO, T., SHIROISHI, T., AIBA, A., and KAMIJO, R. (2009). Essential mesenchymal role of small GTPase Rac1 in interdigital programmed cell death during limb development. Dev Biol. 335: 396-406.

SUDA N., ITOH T., NAKATO R., SHIRAKAWA D., BANDO M., KATOU Y., KATAOKA K., SHIRAHIGE K., TICKLE C., and TANAKA M. (2014). Dimeric combinations of MafB, cFos and cJun control the apoptosis-survival balance in limb morphogenesis. Development 141: 2885-2894

TALAMILLO, A., DELGADO, I., NAKAMURA, T., DE-VEGA, S., YOSHITOMIY., UNDA, F., BIRCHMEIER, W., YAMADA, Y., and ROS, M.A. (2010). Role of Epiprofin, a zinc-finger transcription factor, in limb development. Dev Biol. 337: 363-374.

TONÉ, S., and TANAKA, S.(1997). Analysis of relationship between programmed cell death and cell cycle in limb-bud. Horm Res. 48 Suppl 3: 5-10.

TRIPATHI, G., SALIH, D.A., DROZD, A.C., COSGROVE, R.A., COBB, L.J., and PELL, J.M. (2009). IGF-independent effects of insulin-like growth factor binding protein-5 (lgfbp5) in vivo. FASEB J. 23: 2616-2626

VASEY, D.B., WOLF, C.R., BROWN, K., andWHITELAW, C.B. (2011). Spatial p21 expression profile in the mid-term mouse embryo. Transgenic Res. 20: 23-28.

VAN BOKHOVEN, H., CELLI, J., VAN REEUWIJK,J., RINNE, T., GLAUDEMANS, B., VAN BEUSEKOM, E., RIEU P., NEWBURY-ECOB, R.A., CHIANG, C., and BRUNNER, H.G. (2005). MYCN haploinsufficiency is associated with reduced brain size and intestinal atresias in Feingold syndrome. Nat Genet. 37: 465-467.

VAN KLEFFENS, M., GROFFEN, C., ROSATO, R.R., VAN DEN EIJNDE, S.M., VAN NECK,J.W., LINDENBERGH-KORTLEVE, D.J, ZWARTHOFF, E.C, and DROP, S.L. (1998). mRNA expression patterns of the IGF system during mouse limb bud development, determined by whole mount in situ hybridization. Mol Cell Endocrinol. 138: 151-161.

VARGESSON, N., LURIA, V., MESSINA, I., ERSKINE, L., and LAUFER, E. (2001). Expression patterns of Slit and Robo family members during vertebrate limb development. Mech Dev. 106: 175-180.

VILLACORTE, M., SUZUKI, K., HAYASHI, K., DE SOUSALOPES, S.C., HARAGUCHI, R., TAKETO, M.M., NAKAGATA, N., and YAMADA, G. (2010). Antagonistic crosstalk of Wnt/beta-catenin/Bmp signaling within the Apical Ectodermal Ridge (AER) regulates interdigit formation. Biochem Biophys Res Commun. 391: 1653-1657.
VRIZ, S., REITER,S., and GALLIOT, B. (2014). Cell Death: A Program to Regenerate. In: Mechanism of Regeneration Book Series: Curr. Top. Dev. Biol. (Galliot, B Ed) 108: 121-151.

WANG, C.K., OMI, M., FERRARI, D., CHENG, H.C., LIZARRAGA, G., CHIN, H.J. UPHOLT, W.B., DEALY, C.N., and KOSHER, R.A. (2004). Function of BMPs in the apical ectoderm of the developing mouse limb. Dev Biol. 269: 109-122.

WANG,J, and LENARDO, M.J. (2000). Roles of caspases in apoptosis, development, and cytokine maturation revealed by homozygous gene deficiencies. $J$ Cell Sci 113: 753-757.

WILKIE, A.O., PATEY, S.J., KAN, S.H., VAN DEN OUWELAND, A.M., and HAMEL, B.C. (2002). FGFs, their receptors, and human limb malformations: clinical and molecular correlations. Am J Med Genet. 112: 266-278.

WONG Y.L., BEHRINGER, R.R., and KWAN, K.M. (2012). Smad1/Smad5 signaling in limb ectoderm functions redundantly and is required for interdigital programmed cell death. Dev Biol. 363: 247-257.

YE, Y., TINARI, A., MALORNI, W., LOCKSHIN, R.A., and ZAKERI, Z. (2009). Activation of cyclin-dependent kinase 5 is a consequence of cell death. $J$ Biomed Biotechnol. 2009: 805709

ZHAO, X., BRADE, T., CUNNINGHAM, T.J., and DUESTER, G. (2010). Retinoic acid controls expression of tissue remodeling genes Hmgn1 and Fgf18 at the digit-interdigit junction. Dev Dyn. 239: 665-671.

ZHANG, Q., AHUJA, H.S., ZAKERI, ZF, and WOLGEMUTH, DJ. (1997). Cyclindependent kinase 5 is associated with apoptotic cell death during development and tissue remodeling. Dev Biol. 183: 222-233.

ZOU H., NISWANDER, L. (1996). Requirement for BMP signaling in interdigital apoptosis and scale formation. Science. 272: 738-741.

ZÜLCH, A., BECKER, M.B., and GRUSS, P. (2001). Expression pattern of Irx1 and Irx2 during mouse digit development. Mech Dev. 106: 159-162.

ZUZARTE-LUIS, V., BERCIANO, M.T., LAFARGA, M., and HURLÉ.JM. (2006). Caspase redundancy and release of mitochondrial apoptotic factors characterize interdigital apoptosis. Apoptosis. 11: 701-715

ZUZARTE-LUIS, V., MONTERO, J.A., KAWAKAMI, Y., IZPISUA-BELMONTE, J.C., and HURLE, J.M. (2007). Lysosomal cathepsins in embryonic programmed cell death. Dev Biol. 301: 205-217. 


\section{Further Related Reading, published previously in the Int. J. Dev. Biol.}

Revisiting DNA damage repair, p53-mediated apoptosis and cisplatin sensitivity in germ cell tumors Francesca Cavallo, Darren R. Feldman and Marco Barchi Int. J. Dev. Biol. (2013) 57: 273-280 http://dx.doi.org/10.1387/ijdb. 130135mb

Regulation of programmed cell death during neural induction in the chick embryo Anna Gibson, Neil Robinson, Andrea Streit, Guojun Sheng and Claudio D. Stern

Int. J. Dev. Biol. (2011) 55: 33-43

http://dx.doi.org/10.1387/ijdb. 103233sg

Life-giving caspases: revealing new roles during mouse embryo preimplantation development

Dolores Busso, Calixto Dominguez, Tomas Perez-Acle and Ricardo D. Moreno

Int. J. Dev. Biol. (2010) 54: 857-865

http://dx.doi.org/10.1387/ijdb. 092921db

Apoptosis in Drosophila: compensatory proliferation and undead cells Francisco A. Martín, Ainhoa Peréz-Garijo and Ginés Morata

Int. J. Dev. Biol. (2009) 53: 1341-1347

http://dx.doi.org/10.1387/ijdb. 072447fm

Key apoptosis regulating proteins are down-regulated during postnatal tissue development

Shane D. Madden, Maryanne Donovan and Thomas G. Cotter

Int. J. Dev. Biol. (2007) 51: 415-424

http://dx.doi.org/10.1387/ijdb. 062263sm

5 yr ISI Impact Factor $(2013)=2.879$
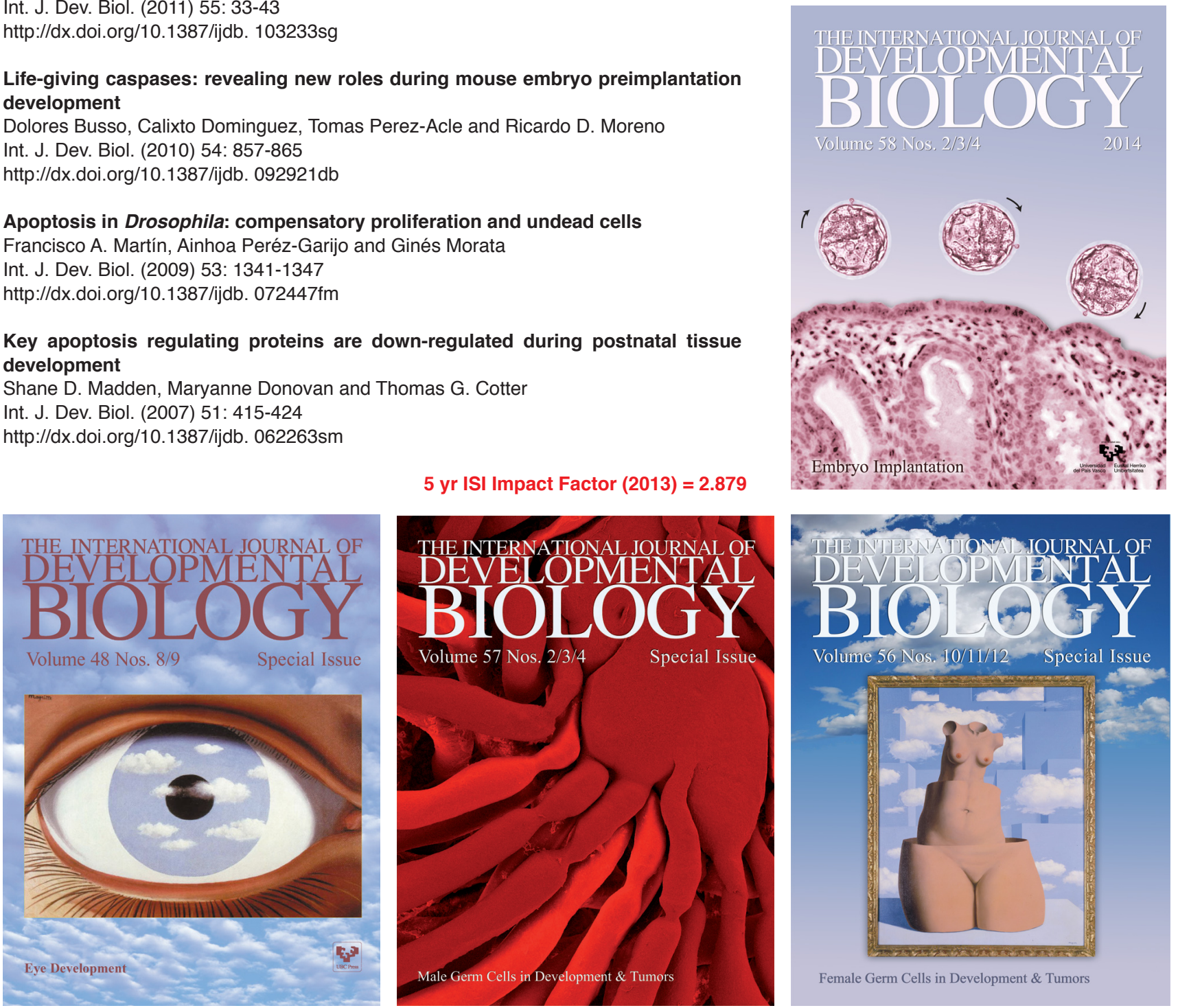